\title{
A preliminary investigation of the water use efficiency of sweet sorghum for biofuel in South Africa
}

\author{
MG Mengistu' 2* , JM Steyn ${ }^{3}$, RP Kunz', I Doidge ${ }^{4}$, HB Hlophe ${ }^{3}$, CS Everson', GPW Jewitt' and AD Clulow ${ }^{1}$ \\ ${ }^{1}$ Centre for Water Resources Research (CWRR), School of Agricultural, Earth and Environmental Sciences, University of KwaZulu-Natal, \\ Pietermaritzburg, South Africa \\ ${ }^{2}$ South African Weather Service, Private Bag X097, Pretoria, South Africa \\ ${ }^{3}$ Department of Plant Production and Soil Science, University of Pretoria, Pretoria, South Africa \\ ${ }^{4}$ African Centre for Crop Improvement (ACCI), School of Agricultural, Earth and Environmental Sciences, University of KwaZulu-Natal, Pietermaritzburg,
} South Africa

\begin{abstract}
Sweet sorghum (Sorghum bicolor (L.) Moench) has been recognized globally as a potential biofuel crop for ethanol production. Sweet sorghum is a drought-tolerant crop that is widely adapted to different environmental growing conditions. The aim of this study was to determine the water use efficiency (utilisable yield per unit amount of water used) of drip-irrigated sweet sorghum (variety Sugargraze) under two different climatic conditions in South Africa. The sweet sorghum trials were conducted at Ukulinga research farm (University of KwaZulu-Natal, Pietermaritzburg) and Hatfield experimental farm (University of Pretoria, Pretoria), South Africa. Field trials were conducted in two successive seasons, viz., 2010/11 and 2011/12. Seasonal water use was estimated using eddy covariance and surface renewal methods. Fresh and dry aboveground biomass yield, stalk yield and stalk Brix \% were measured at final harvest. Theoretical ethanol yield was calculated from fresh stalk yield and Brix \%. Water use for the two growing seasons was $415 \mathrm{~mm}$ at Ukulinga and $398 \mathrm{~mm}$ at Hatfield. The ethanol water use efficiency (WUE) values for the sweet sorghum at Ukulinga were 0.27 and $0.60 \mathrm{~L} \cdot \mathrm{m}^{-3}$ for 2010/11 and 2011/12 growing seasons, respectively. The ethanol WUE estimate of the sweet sorghum at Hatfield was $0.53 \mathrm{~L} \cdot \mathrm{m}^{-3}$ for the $2010 / 11$ season and $0.70 \mathrm{~L} \cdot \mathrm{m}^{-3}$ for the $2011 / 12$ growing season. WUE estimates of the sweet sorghum crop were higher for Hatfield compared to Ukulinga research farm. The results from this study showed that the WUE of sweet sorghum was sensitive to plant density. The WUEvalues confirm that sweet sorghum has high WUE under different climatic conditions.
\end{abstract}

Keywords: water use efficiency; ethanol yield; biofuel crop; plant density, sweet sorghum, South Africa

\section{INTRODUCTION}

Biofuels are being promoted as one of the solutions to rising fuel prices, growing energy demands, and the need to curb greenhouse gas emissions as well as boost jobs and incomes in rural areas (IWMI, 2008). While biofuel production can provide jobs and new sources of income for the rural poor, particularly smallholder farmers, several concerns have been raised regarding potential impacts on food security and human livelihoods, as well as the potential biophysical impacts of largescale biofuel production (Jewitt and Kunz, 2011). The South African policy document, 'The Biofuels Industrial Strategy of South Africa' (DME, 2007) is generally considered to be conservative, tempering the international drive towards large-scale biofuel production with a pragmatic approach towards a goal of $2 \%$ biofuel penetration within 5 years. The initial focus is on the production of bioethanol from sugarcane as well as grain sorghum, and biodiesel from sunflower and canola as well as soybeans. Since food security is a major concern, maize has been excluded as a potential feedstock for bioethanol production.

Water is required throughout the entire biofuel supply chain, but mainly for the production of feedstock. The water used to grow feedstock has the potential to increase the demand for water in a particular catchment, which could negatively

\footnotetext{
* To whom all correspondence should be addressed.

× +27-722030954; e-mail: Michael.Mengistu@weathersa.co.za; mgmengistu@gmail.com

Received: 22 April 2015; accepted in revised form 20 November 2015
}

impact water availability for other uses. Water use of biofuel feedstock is therefore a critical component to assess in the production of renewable fuel on a sustainable basis. Globally, agriculture is the biggest user of available freshwater resources (Grafton and Hussey, 2011). For instance, Mul (2009) estimated that 70 to $90 \%$ of 'blue water' extraction (i.e. water from rivers, lakes, reservoirs and groundwater) in sub-Saharan Africa is used by irrigated agriculture. Non-productive soil water fluxes (e.g. soil water evaporation and deep percolation) occur in irrigated agriculture and represent water that cannot be used for crop growth (via transpiration). It is also important to understand and quantify these water fluxes, in order to improve crop water use efficiency in regions where irrigation is practised.

Water use efficiency (WUE) is defined in terms of utilisable portion of the aboveground biomass (i.e. fruit, grain or seed yield in $\mathrm{kg}$ ) per unit amount of evapotranspiration (in $\mathrm{m}^{3}$ of water). WUE has been anticipated to become an important criterion in deciding competing land-use scenarios in catchment planning (Calder, 2005). In South Africa, a need for WUE information is expected to develop as catchment management agencies are constituted to manage water resource allocations in the various water management areas of the country (Nomquphu et al., 2007). However, the necessary scientific information required for this purpose is currently inadequate, and requires a combination of bio-physical data (e.g. yields produced per volume of water used) and economic data (e.g. value or profit of yield per unit of water used). There is also a clear need to develop drought-resistant cultivars with higher yield under conditions of water deficit. Selecting more water-efficient cultivars is an important pathway to reducing water use in 
a water-scarce region and improving WUE in crop production. Some feedstocks (e.g. sorghum) are reported to be more drought tolerant than others (Vasilakoglou et al., 2011). WUE is also an important consideration when breeding for better yields in water-limited environments (Passioura and Angus, 2010). Improvements in WUE could decrease crop water requirements when water resources are limited. However, there has been little research on the WUE of biofuel feedstocks and limited information is available for other crops or vegetation types in South Africa. Addressing this knowledge gap is vital for sustainable biofuel production.

Sweet sorghum is a fast growing $\mathrm{C}_{4}$ crop with high photosynthetic efficiency, high biomass production potential, and high sugar accumulation in the stalks (Almodares and Hadi, 2009). Sweet sorghum is adaptable to a wide range of growing conditions and has many good characteristics such as drought resistance, waterlogging tolerance, and salinity resistance (Almodares and Hadi, 2009). Sweet sorghum is also well adapted to sub-tropical and temperate regions of the world (Reddy et al., 2007). The Brix (total soluble sugars) of the juice in the stalk can vary from 7 to $24 \%$ depending on the sweet sorghum variety. Stem height increases with day length and therefore stems are shorter when grown at the Equator. The stem is usually 60 to $80 \%$ of the total above-ground mass. After blooming and pollination, sweet sorghum enters the grain development stage, with the fresh panicle weight ranging from 6 to $20 \%$ of the total biomass. Average thousand-seed weight is $21 \mathrm{~g}$ and varies from $16-28 \mathrm{~g}$ (Guiying et al., 2003).

Unlike other bioenergy feedstocks, sweet sorghum produces food products and other valuable by-products (from its grain, stalks and leaves), thus eliminating the 'food vs. fuel' issue so often raised by biofuel critics. Sweet sorghum can be used for food, fuel, fodder, fibre and fertilizer production. Hence, sweet sorghum is a multi-purpose crop which can be cultivated for the simultaneous production of (ABW, 2010): grain from its panicle (for food, mainly flat breads and porridges); sugary juice from its stalk (for making syrup or ethanol); and bagasse and green leaves (as an excellent fodder for animals, or as organic fertilizer, or for paper manufacturing).

This study is part of a biofuels project (WRC project K5/1874) entitled: 'Water use of cropping systems adapted to bio-climatic regions in South Africa and suitable for biofuel production' (WRC, 2010). The aim of this study is to estimate WUE of well-watered sweet sorghum with reference to the biomass yield, biofuel yield, and seasonal water use over the full productive cycle.

\section{MATERIALS AND METHODS}

\section{Trial site description}

Field experiments were conducted at Ukulinga, the research and training farm of the University of KwaZulu-Natal, Pietermaritzburg, South Africa (latitude $29^{\circ} 40^{\prime}$ S, longitude $30^{\circ} 24^{\prime} \mathrm{E}$, altitude $800 \mathrm{~m}$ amsl) and Hatfield experimental farm, University of Pretoria, Pretoria, South Africa (latitude $25^{\circ} 45^{\prime} \mathrm{S}$, longitude $28^{\circ} 16^{\prime} \mathrm{E}$, altitude $1327 \mathrm{~m}$ amsl).

Ukulinga receives an average annual rainfall of $750 \mathrm{~mm}$ over 113 rain days, with $23 \%$ of the mean annual precipitation (MAP) falling during the winter months. The two wettest months are January and February which receive average monthly totals of 108 and $103 \mathrm{~mm}$, respectively. Ukulinga experiences warm to hot summers and mild winters with occasional frost (Camp, 1997). The mean annual temperature is $18.4^{\circ} \mathrm{C}$
(Camp, 1997). The Hatfield experimental farm is in the country's summer rainfall region, characterized by high intensity and short duration rainfall events with sunny periods between rains. The mean annual rainfall is $670 \mathrm{~mm}$, which is concentrated mainly in the months of October to March. Monthly mean minimum temperature is $1.5^{\circ} \mathrm{C}$ (July) and monthly mean maximum temperature is $30^{\circ} \mathrm{C}$ (January). Frost spells may occur during winter (Alemayehu et al., 2009).

For both Ukulinga and Hatfield the sweet sorghum variety used was Sugargraze, which was the only hybrid available from local suppliers. It is an Australian hybrid but is sold locally by Klein Karoo Seed marketing (K2 Seed Marketing). Sugargraze is a sweet sorghum variety with thick stems, long leaf blades, and oval round seeds. It is widely adapted to most soil types, preferably heavy soils with $\mathrm{pH}$ range of 5.5-7.5 (K2 Seed Marketing, 2015).

At the Ukulinga research farm, the sweet sorghum (Sugargraze) trials were conducted over 2 growing seasons on an $80 \times 80 \mathrm{~m}$ plot. In the first season, the sweet sorghum trial was planted in the first week of December 2010 and harvested in the first week of May 2011. The second growing season was from mid-December 2011 to the first week of May 2012. Plant rows were spaced $0.9 \mathrm{~m}$ apart, with an in-row spacing of $0.14 \mathrm{~m}$, resulting in a plant population of 81813 plants/ha. Planting density was increased in the second season to 134609 plants/ha. The row spacing was $0.9 \mathrm{~m}$ but intra-row spacing was changed to $0.1 \mathrm{~m}$. The additional plants were due to tillering.

The Ukulinga soils are dominated by the Westleigh soil form (Soil Classification Working Group, 1991) with a permanent wilting point and field capacity of 172-194 and $228-233 \mathrm{~mm} \cdot \mathrm{m}^{-1}$, respectively. The soil texture is predominately a clay loam, with clay content increasing from $29 \%$ to $35 \%$ with depth (Lorentz et al., 2001; Moodley et al., 2004).

The Ukulinga trials were fertilized with $300 \mathrm{~kg} \cdot \mathrm{ha}^{-1}$ of 2:3:4(30) basal fertilizer before planting and $400 \mathrm{~kg} \cdot \mathrm{ha}^{-1}$ of LAN fertilizer was applied in 2 split applications using a fertilizer spreader after the plants were knee high. Pyrethroid insecticide was applied after planting and when the plants were $1 \mathrm{~m}$ high.

Drip irrigation was used to supplement rainfall in order to ensure optimal growing conditions. The irrigation was switched off 3 weeks prior to the harvest date. The plants were harvested when the grain reached the hard dough stage. The hard dough stage was found to be the optimum stage to achieve maximum stalk sugar yield.

Two trials were also established at the Hatfield experimental farm in Pretoria on 7 December 2010 and 1 December 2011. The same sweet sorghum variety used at Ukulinga was used in both trials in a uniform block of $80 \times 80 \mathrm{~m}$. Drip irrigation was installed to supplement rainfall when needed in order to ensure optimal growing conditions. Plant rows were spaced $0.9 \mathrm{~m}$ apart, with an in-row spacing of $0.2 \mathrm{~m}$, giving a plant population of about 55000 plants/ha. Plant density was increased in the second season to $86000 \mathrm{plants} / \mathrm{ha}$. The row spacing was maintained at $0.9 \mathrm{~m}$ but intra-row spacing was reduced to $0.125 \mathrm{~m}$. Harvesting commenced on 10 May 2011 and 7 May 2012 and lasted for about 2 weeks.

The soil for the Hatfield trial was a sandy clay loam with a permanent wilting point and field capacity of 171-192 and 292-314 $\mathrm{mm} \cdot \mathrm{m}^{-1}$, respectively, for the top $0.6 \mathrm{~m}$. The soil at Hatfield is a Hutton (Soil Classification Working Group, 1991) soil with a sandy clay texture.

Before planting of the Hatfield trials, $50 \mathrm{~kg} \cdot \mathrm{ha}^{-1} \mathrm{~N}$, $75 \mathrm{~kg} \cdot \mathrm{ha}^{-1} \mathrm{P}$ and $100 \mathrm{~kg} \cdot \mathrm{ha}^{-1} \mathrm{~K}$ (as 2:3:4(30) compound fertilizer) was applied and incorporated into the soil. An additional 
$75 \mathrm{~kg} \cdot \mathrm{ha}^{-1} \mathrm{~N}$ (as LAN, $28 \% \mathrm{~N}$ ), was side dressed 4 weeks after planting to give a total of $125 \mathrm{~kg} \cdot \mathrm{ha}^{-1} \mathrm{~N}$. Fertilizer rates were based on soil chemical analysis results and fertilizer guidelines for fodder sorghum (FSSA, 2003), and were similar to the rates reported for sweet sorghum studies elsewhere (e.g., Vasilakoglou et al. 2011). Weeds were controlled manually and aphid infestation was controlled by spraying a systemic insecticide (cypermethrin) at recommended rates $\left(300 \mathrm{~mL} \cdot \mathrm{ha}^{-1}\right)$.

\section{Instrumentation and sampling methodology}

Water use was estimated as the total water use of the crop from planting date to harvest. It is expressed as the total evaporation (soil evaporation + transpiration + interception) in $\mathrm{mm}$ or $\mathrm{m}^{3}$ for the growing period. Total evaporation was estimated using the eddy covariance and the surface renewal (Paw et al., 2005; Mengistu and Savage, 2010) methods as the residual of the shortened energy balance equation. Neglecting advection and the stored canopy heat, the shortened energy balance equation was used to estimate the latent energy flux $\lambda \mathrm{E}\left(\mathrm{W} \cdot \mathrm{m}^{-2}\right)$, which is the energy equivalent of total evaporation as:

$$
\lambda \mathrm{E}=R_{n}-G-H
$$

where: $R_{n}$ is the net irradiance $\left(\mathrm{W} \cdot \mathrm{m}^{-2}\right), G$ the soil heat flux $\left(\mathrm{W} \cdot \mathrm{m}^{-2}\right)$, and $H$ the sensible heat flux $\left(\mathrm{W} \cdot \mathrm{m}^{-2}\right)$.

An Applied Technologies, Inc. (ATI) sonic anemometer ('Sx' style probe) was used as an eddy covariance system to measure three-dimensional wind velocity components, sensible heat flux density, and indirectly the latent energy flux as a residual of the shortened energy balance equation. The sonic anemometer was connected to a CR3000 datalogger (Campbell Scientific Inc., Logan, Utah, USA). All eddy covariance data were sampled at a frequency of $10 \mathrm{~Hz}$ and data processed online in the datalogger. The high frequency data, the 2-min, and 30 -min averages of the covariances between wind speed $(u, v$, and $w$ ), sonic temperature, $T_{s}$, and wind direction were calculated and stored for further analysis. For the surface renewal method, one unshielded type-E fine-wire thermocouple (75- $\mu \mathrm{m}$ diameter) was used to measure air temperature at $0.5 \mathrm{~m}$ above the canopy. Air temperature data was also sampled at a frequency of $10 \mathrm{~Hz}$ using differential thermocouple measurements. Time lags of $0.40 \mathrm{~s}$ and $0.80 \mathrm{~s}$ were used for the surface renewal analysis before forming the second, third and fifth order of air temperature structure function values as required by the Van Atta (1977) approach. The data were then averaged and stored every $2 \mathrm{~min}$ in the datalogger.

Additional measurements included the remaining components of the energy balance. Net irradiance was measured using a $Q^{\star} 7$ net radiometer (REBS, Seattle, Washington, USA). Two Hukse flux plates (HFP01-15, Delft, The Netherlands) were used to measure soil heat flux density at a depth of $80 \mathrm{~mm}$ and a system of parallel-thermocouples at depths of 20 and $60 \mathrm{~mm}$ were used to calculate the heat stored above the plates. Soil water content was measured using a Campbell Scientific TDR 100 system at $0.1,0.2,0.4$, and $0.6 \mathrm{~m}$ depths below the soil surface.

\section{Yield and water use efficiency}

A total of 10 sample blocks were selected in the $80 \times 80 \mathrm{~m}$ trial for the yield analysis at Ukulinga. The sizes of the blocks were six $20 \times 10 \mathrm{~m}$ and four $10 \times 10 \mathrm{~m}$ blocks. The sweet sorghum stalks were harvested manually with secateurs. The leaves and heads were stripped from the stalks and placed in labelled bags for weighing. This was done to determine the portion of leaves and heads as a percentage of the aboveground biomass on a fresh mass basis. Each line of harvested stems was then bundled and weighed in the field to determine the yield of fresh stalk per block. One line per sample plot was then placed in ovens for $24 \mathrm{~h}$ at $80^{\circ} \mathrm{C}$ to dry to constant mass. Once dried, the samples were re-weighed to determine the total dry matter yield per block as well as the dry matter yield of each component (stalks, leaves and heads). For the Hatfield trials stalk and aboveground biomass yields were determined from 10 blocks consisting of a total area of $20 \times 10 \mathrm{~m}$ each. The yield analysis was similar to the sweet sorghum trial at Ukulinga.

For sugar content (Brix) determination, 20 stripped stalks of about $1 \mathrm{~m}$ in length were taken per sample, tied into bundles and placed in labelled polypropylene bags. The samples were kept cool by refrigeration to delay the reduction in sugar properties after harvesting. The average Brix content of each sample was determined using a laboratory refractometer, which was calibrated using sucrose, to give a reading in degrees Brix. One degree $\mathrm{Brix}\left({ }^{\circ} \mathrm{Bx}\right)$ is equivalent to $1 \mathrm{~g}$ of sucrose in $100 \mathrm{~g}$ of aqueous solution and gives an indication of the ratio of total soluble sugars to water in the sample. By definition, Brix values can also be reported as per cent values.

The theoretical ethanol yield was estimated from the stalk Brix using an equation similar to that published by SakellariouMakrantonaki et al. (2007), Zhao et al. (2009) and Vasilakoglou et al. (2011):

Total ethanol yield $\left(\mathrm{L} \cdot \mathrm{ha} \mathrm{a}^{-1}\right)=$ fresh stalk Brix $(\%) \times$ fresh stalk biomass $\left(\mathrm{t} \cdot \mathrm{ha}^{-1}\right) \times 10 \times 0.511$ (conversion factor of ethanol from sugar) $\times 0.85$ (total fermentable sugar peaks at 0.85$) \times 0.90$ (process efficiency of ethanol from sugar) $\times(1.00 / 0.79)$ (specific gravity of ethanol, $\mathrm{g} \cdot \mathrm{mL}^{-1}$ )

Biomass WUE was determined as the ratio of total aboveground dry matter (TDM) and fresh stalk yield in tha ${ }^{-1}$ to seasonal water use $\left(\mathrm{m}^{3} \cdot \mathrm{ha}^{-1}\right)$. Sugar WUE was determined as the ratio of sucrose (Brix) yield to seasonal water use. Ethanol WUE was also estimated as the ratio of ethanol yield to seasonal water use.

\section{RESULTS AND DISCUSSION}

\section{Climate data}

The main climatic factors which affect water use efficiency are evaporative demand of the atmosphere, solar radiation and rainfall. The evaporative demand of the atmosphere is largely driven by the vapour pressure deficit (VPD) and net irradiance available at the surface. Reference evapotranspiration (ET) and VPD are good indicators of the atmospheric demand. However, $\mathrm{ET}_{\mathrm{o}}$ is considered as a better normalizing factor for evaporative demand than VPD. Climate data that are used for calculating $\mathrm{ET}_{\mathrm{o}}$ include solar radiation, air temperature, relative humidity, and wind speed. Weather parameters which affect crop yield and total evaporation are summarized in Tables 1 and 2 .

The sweet sorghum trials were planted in December and were harvested in May for both growing seasons. A summary of the monthly weather data for the 2010/11 and 2011/12 growing seasons at the Ukulinga research farm are presented in Table 1. A summary of the monthly weather data for the 2010/11 and 2011/12 growing seasons at the Hatfield experimental farm are presented in Table 2. 
TABLE 1

Summary of the monthly weather data for the 2010/11 and 2011/12 growing seasons at the Ukulinga research farm (Pietermaritzburg)

\begin{tabular}{|l|c|c|c|c|c|c|c|c|}
\hline \multirow{2}{*}{ Year } & \multirow{2}{*}{ Month } & $\begin{array}{c}\boldsymbol{R}_{\mathbf{s}} \\
\left(\mathbf{M}^{\mathbf{S}}\right. \\
\left.\mathbf{m}^{-2}\right)\end{array}$ & $\begin{array}{c}\boldsymbol{T}_{\max } \\
\left({ }^{\circ} \mathbf{C}\right)\end{array}$ & $\begin{array}{c}\boldsymbol{T}_{\text {min }} \\
\left({ }^{\circ} \mathbf{C}\right)\end{array}$ & $\begin{array}{c}\mathbf{R H}_{\max } \\
(\mathbf{\%})\end{array}$ & $\begin{array}{c}\mathbf{R H}_{\min } \\
(\mathbf{\%})\end{array}$ & $\begin{array}{c}\text { Rain } \\
(\mathbf{m m})\end{array}$ & $\begin{array}{c}\mathbf{E T}_{\mathbf{o}} \\
(\mathbf{m m})\end{array}$ \\
\hline 2010 & 12 & 545.9 & 29.9 & 17.4 & 96.7 & 59.0 & 136.0 & 88.7 \\
\hline 2011 & 01 & 585.8 & 31.5 & 18.0 & 97.3 & 56.1 & 145.7 & 96.5 \\
\hline 2011 & 02 & 553.9 & 32.4 & 18.6 & 99.8 & 47.3 & 63.3 & 99.7 \\
\hline 2011 & 03 & 515.7 & 31.4 & 17.8 & 96.0 & 38.5 & 53.8 & 109.1 \\
\hline 2011 & 04 & 405.0 & 30.4 & 15.0 & 96.2 & 49.3 & 71.8 & 66.0 \\
\hline 2011 & 05 & 348.6 & 21.3 & 12.5 & 86.5 & 33.4 & 48.3 & 56.8 \\
\hline 2011 & 12 & 534.0 & 27.0 & 15.8 & 97.7 & 53.2 & 76.0 & 101.2 \\
\hline 2012 & 01 & 587.1 & 29.3 & 17.2 & 96.7 & 46.8 & 61.4 & 116.3 \\
\hline 2012 & 02 & 478.9 & 30.1 & 17.8 & 96.7 & 45.5 & 31.9 & 98.3 \\
\hline 2012 & 04 & 480.1 & 28.4 & 15.8 & 96.2 & 41.8 & 103.1 & 97.3 \\
\hline 2012 & 05 & 338.6 & 24.9 & 11.7 & 91.9 & 32.0 & 14.2 & 64.2 \\
\hline
\end{tabular}

\section{Water use}

Daily water use of sweet sorghum at Ukulinga varied between 0.5 and $6.0 \mathrm{~mm}$ in the 2010/11 growing season and was higher in January and February 2011 due to the higher solar radiation and air temperatures that existed during these summer months (Fig. 1). Daily ET was generally less than $2 \mathrm{~mm} \cdot \mathrm{day}^{-1}$ on cool cloudy days when the atmospheric evaporative demand was low. On these cool days, the radiation demand was below $4 \mathrm{~mm}$ of energy equivalent units $(1 \mathrm{~mm} \mathrm{ET}=2.43 \mathrm{MJ})$. On clear sunny days the water use was greater than $3 \mathrm{~mm} \cdot$ day $^{-1}$. The change in profile volumetric soil water content over time is also shown in Fig. 1. The total seasonal water use estimate of the sweet sorghum crop at Ukulinga was $394 \mathrm{~mm}$ for the 2010/11 growing season (Table 3). The water use of the sweet sorghum crop for the 2011/12 growing season (Fig. 2) was similar to the 2010/11 growing season (Fig. 1). The maximum $8.5 \mathrm{~mm}$ of total evaporation estimated on 28 February 2012 (Fig. 2) was due to advective conditions on that day when a hot, dry wind prevailed. The total seasonal water use estimate for the sweet sorghum crop at Ukulinga was $436 \mathrm{~mm}$ for the 2011/12 growing season (Table 3).

The range in daily water use of the sweet sorghum at Hatfield varied between 0.5 and $5.7 \mathrm{~mm}$ (Fig. 3), almost identical to that observed at Ukulinga. A similar pattern of greater water use in January and February 2011 and 2012 was also noted. The increase in soil water content in the third week of March 2011 was due to a total of $93 \mathrm{~mm}$ rain which fell over the 7 days. The water use estimates gradually decreased to an average monthly estimate of less than $2 \mathrm{~mm}$ during the months of March and April. The total seasonal water use in 2010/11 for the sweet sorghum crop at Hatfield was $391 \mathrm{~mm}$ (Table 4). This value is similar to the water use estimates obtained for Ukulinga. The daily variation in estimated total evaporation for the 2011/12 growing season at Hatfield is shown in Fig. 4. The daily water use declined relatively steadily from highest values $(4.8 \mathrm{~mm})$ in mid-January to values below $2 \mathrm{~mm}$ in April. The total seasonal water use in 2011/12 for the sweet sorghum crop at Hatfield was $405 \mathrm{~mm}$ (Table 4).
TABLE 2

Summary of the monthly weather data for the 2010/11 and 2011/12 growing seasons at the Hatfield experimental farm (Pretoria)

\begin{tabular}{|c|c|c|c|c|c|c|c|c|}
\hline \multirow[t]{2}{*}{ Year } & \multirow[t]{2}{*}{ Month } & $\begin{array}{c}R_{s} \\
\left(\mathbf{M J}^{-}\right. \\
\left.\mathbf{m}^{-2}\right)\end{array}$ & $\begin{array}{l}T_{\text {max }} \\
\left({ }^{\circ} \mathrm{C}\right)\end{array}$ & $\begin{array}{l}T_{\min } \\
\left({ }^{\circ} \mathrm{C}\right)\end{array}$ & $\begin{array}{c}\mathbf{R H}_{\max } \\
(\%)\end{array}$ & $\underset{\mathbf{( \% )}}{\mathbf{R H}_{\min }}$ & $\begin{array}{l}\text { Rain } \\
\text { (mm) }\end{array}$ & $\begin{array}{c}\mathrm{ET}_{\mathrm{o}} \\
(\mathrm{mm})\end{array}$ \\
\hline & & Total & Mean & Mean & Mean & Mean & Total & Total \\
\hline 2010 & 12 & 443.9 & 28.2 & 15.9 & 85.3 & 32.7 & 199.2 & 131.4 \\
\hline 2011 & 01 & 405.8 & 27.7 & 16.9 & 87.4 & 41.0 & 222.6 & 113.8 \\
\hline 2011 & 02 & 438.6 & 28.6 & 16.2 & 82.0 & 25.8 & 36.3 & 118.3 \\
\hline 2011 & 03 & 651.2 & 29.2 & 15.9 & 81.5 & 29.4 & 247.5 & 128.0 \\
\hline 2011 & 04 & 444.0 & 23.8 & 12.4 & 84.9 & 35.3 & 47.4 & 85.0 \\
\hline 2011 & 05 & 476.5 & 22.5 & 8.1 & 84.0 & 26.7 & 17.7 & 70.0 \\
\hline 2011 & 12 & 621.6 & 28.0 & 16.3 & 82.6 & 30.2 & 103.7 & 129.4 \\
\hline 2012 & 01 & 675.1 & 29.6 & 16.5 & 82.6 & 25.7 & 68.3 & 149.3 \\
\hline 2012 & 02 & 604.6 & 30.5 & 17.1 & 80.5 & 23.5 & 85.0 & 113.0 \\
\hline 2012 & 03 & 618.2 & 30.0 & 15.1 & 76.8 & 15.3 & 31.5 & 118.2 \\
\hline 2012 & 04 & 523.2 & 26.1 & 10.2 & 83.3 & 20.8 & 15.4 & 98.9 \\
\hline 2012 & 05 & 464.0 & 25.5 & 8.7 & 72.9 & 12.7 & 0.0 & 66.9 \\
\hline
\end{tabular}

\begin{tabular}{|l|c|c|c|}
\hline \multicolumn{5}{|c|}{ TABLE 3} \\
\multicolumn{2}{|c|}{$\begin{array}{c}\text { Comparison of sweet sorghum water use obtained at } \\
\text { Ukulinga for both the 2010/11 and 2011/12 growing seasons }\end{array}$} \\
\hline Season & $\begin{array}{c}\text { Growing period } \\
\text { (days) }\end{array}$ & $\begin{array}{c}\text { Water use } \\
\text { (mm) }\end{array}$ & $\begin{array}{c}\text { Water use } \\
\text { ( }^{\mathbf{3}} \cdot \mathbf{h a}^{-1} \text { ) }\end{array}$ \\
\hline $2010 / 11$ & 132 & 394 & 3940 \\
\hline $2011 / 12$ & 145 & 436 & 4360 \\
\hline
\end{tabular}

\begin{tabular}{|c|c|c|c|}
\hline \multicolumn{4}{|c|}{$\begin{array}{l}\text { TABLE } 4 \\
\text { Comparison of sweet sorghum water use obtained at } \\
\text { Hatfield for both the } 2010 / 11 \text { and } 2011 / 12 \text { growing seasons }\end{array}$} \\
\hline Season & \begin{tabular}{|c|} 
Growing period \\
(days)
\end{tabular} & $\begin{array}{c}\text { Water use } \\
(\mathrm{mm})\end{array}$ & $\begin{array}{c}\begin{array}{c}\text { Water use } \\
\left(\mathrm{m}^{3} \cdot \mathrm{ha}^{-1}\right)\end{array} \\
\end{array}$ \\
\hline $2010 / 11$ & 139 & 391 & 3910 \\
\hline $2011 / 12$ & 140 & 405 & 4050 \\
\hline
\end{tabular}

The water use obtained from this study (Tables 3 and 4) are lower than the water use of two sweet sorghum varieties (MN1500 and Keller) reported by Dercas et al. (2001) under Mediterranean climate in Greece, which ranged between 601 to $609 \mathrm{~mm}$ (high irrigation conditions) and 449 to $487 \mathrm{~mm}$ (low irrigation conditions). Wu et al. (2010) reported that the quantity of water required by sweet sorghum was about one third to a half of that for sugarcane, half the amount used by maize and two thirds of that needed for sugarbeet.

\section{Yield estimates}

The average fresh stalk yield of the 10 sample blocks analysed at Ukulinga was 24.4 tha ${ }^{-1}$ with a standard deviation (SD) of 3.4(\%)t.ha $\mathrm{a}^{-1}$ for the 2010/11 growing season and $41.8 \mathrm{t} \cdot \mathrm{ha}^{-1}$ (SD $=5.1 \mathrm{t} \cdot \mathrm{ha}^{-1}$ ) for the 2011/12 growing season (Table 5). The dry stalk yield was calculated from the product of the fresh stalk yield and the stalk dry matter content (e.g. 20.2\% and $22.4 \%$ 


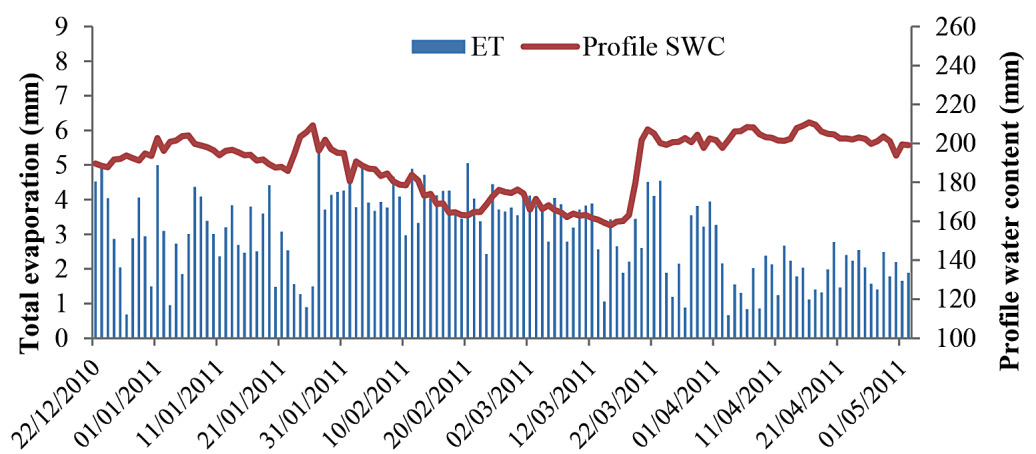

Figure 1

Daily total evaporation estimates from the sweet sorghum canopy along with profile volumetric soil water content over $600 \mathrm{~mm}$ depth at Ukulinga research farm for the 2010/11 growing season

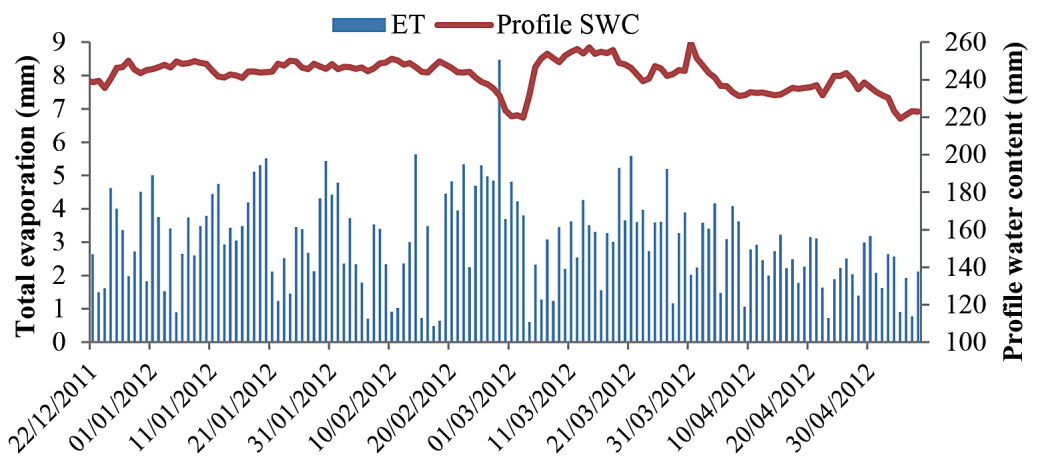

Figure 2

Daily total evaporation estimates from the sweet sorghum canopy along with profile volumetric soil water content over $600 \mathrm{~mm}$ depth at Ukulinga research farm for the 2011/12 growing season

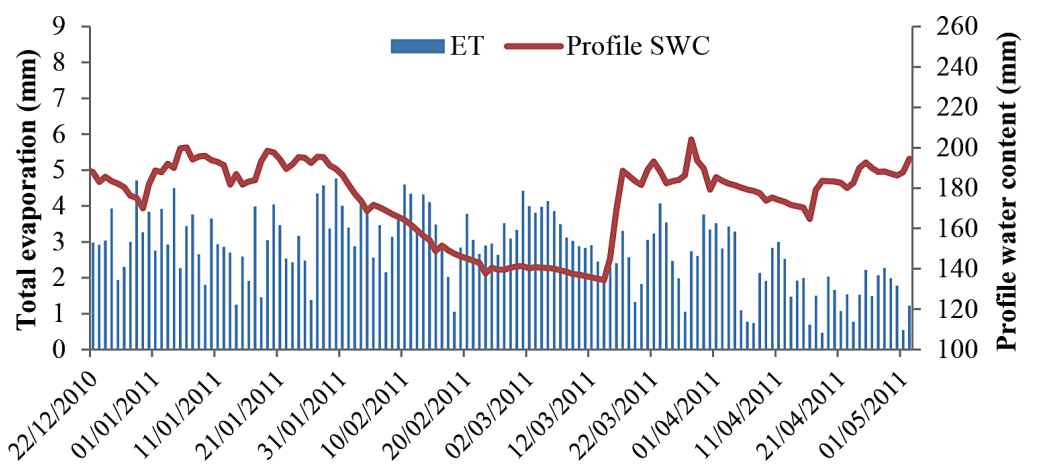

Figure 3

Total evaporation estimates from the sweet sorghum canopy along with profile volumetric soil water content over $600 \mathrm{~mm}$ depth at Hatfield experimental farm for the 2010/11 growing season

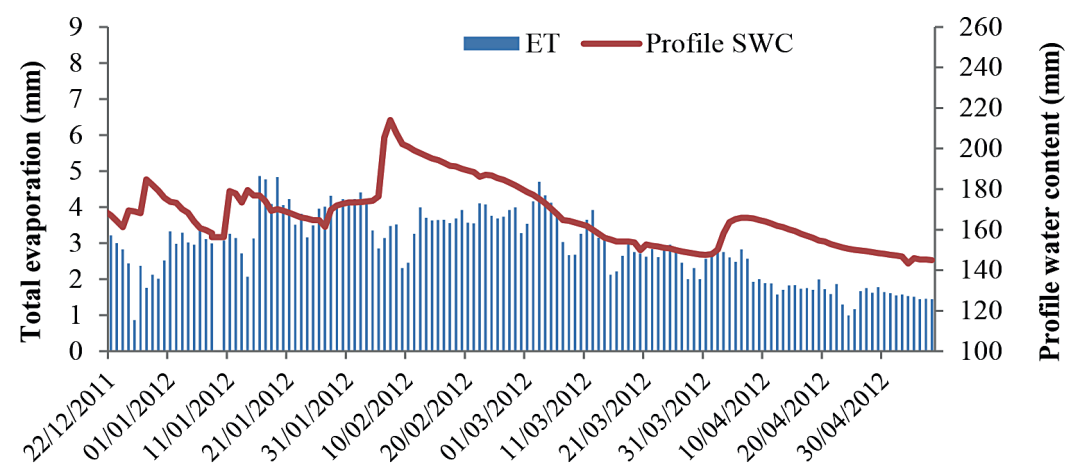

Figure 4

Total evaporation estimates from the sweet sorghum canopy along with profile volumetric soil water content over $600 \mathrm{~mm}$ depth at Hatfield experimental farm for the 2011/12 growing season 
based on mass for the 2010/11 and 2011/12 seasons, respectively). The average fresh stalk yield at Hatfield ranged from $34.1 \mathrm{t} \cdot \mathrm{ha}^{-1}\left(\mathrm{SD}=6.2 \mathrm{t} \cdot \mathrm{ha}^{-1}\right)$ in $2010 / 11$ growing season to 37.6 t.hat ${ }^{-1}\left(S D=9.6\right.$ tha $\left.^{-1}\right)$ in the 2011/12 season as shown in Table 6. The yield for the 2011/12 growing season increased as a result of the increase in planting density (Table 6). The portion of stalks damaged by stalk borer was $5.0 \%$ (2010/11 season) and $8.5 \%$ (2011/12 season) at Hatfield.

In order to compare the yields obtained at Ukulinga and Hatfield with those reported by other researchers, total dry matter (stalk, leaf and head) was used instead of stalk dry matter. Total dry matter is more appropriate for reporting biomass yields when considering second generation conversion technologies.

The total dry matter yield (TDM) of sweet sorghum ranged from 7.3 to 13.1 tha ${ }^{-1}$ at Ukulinga and 14.2 to $18.1 \mathrm{t} \cdot \mathrm{ha}^{-1}$ at Hatfield over both seasons. These values are low compared to those obtained from the available literature. For example, Miller and Ottman (2010) reported aboveground biomass yield range of 23.5 to $26.0 \mathrm{dry} \mathrm{t} \cdot \mathrm{ha}^{-1}$ (average of $25.1 \mathrm{dry}$ t $\cdot h \mathrm{a}^{-1}$ ) under three different irrigation frequencies triggered by $35,50,65 \%$ depletion of plant available soil water. In addition, Turhollow et al. (2010) reported that forage and sweet sorghums have higher aboveground biomass yield potentials of 20 to 40 dry t $\cdot$ ha $^{-1}$ compared to grain sorghum. USDoE (2011) reported that sweet sorghum can potentially yield a dry weight of up to $35 \mathrm{t} \cdot \mathrm{ha}^{-1}$. Zegada-Lizarazu et al. (2012) reported sweet sorghum yields ranging from 8.5 to $20.3 \mathrm{dry} \mathrm{t} \cdot \mathrm{ha}^{-1}$ for temperate, sub-tropical and tropical climates (and sucrose yields from 2.5 to $5.2 \mathrm{t} \cdot \mathrm{ha}^{-1}$ ). Under well-watered conditions Mastrorilli et al. (1995) and Dercas and Liakatas (2007) reported average yields of about $30 \mathrm{t} \cdot \mathrm{ha}^{-1}$, with a total water use between 554 and $657 \mathrm{~mm}$. Sweet sorghum yield is sensitive to planting date and low yields can result if the crop is planted too early (not cold tolerant) or too late (short growing season) (DAFF, 2010; Rao, 2013).

Ethanol yield estimated from the sweet sorghum trials at Ukulinga is given in Table 7. The results show that ethanol yield is associated to stalk yield, which varied at Ukulinga due to the planting density. The sugar content also varied which is a characteristic of the Sugargraze variety under local conditions. The estimated ethanol yield from the sweet sorghum trials at Hatfield is given in Table 8. The highest yields for all parameters were achieved in the 2011/12 season. The stalk Brix was higher at Hatfield compared to Ukulinga, which resulted in a higher theoretical ethanol yield and thus a higher ethanol extraction yield per ton of crop. The average extraction yields obtained from Ukulinga $\left(53.2 \mathrm{~L} \cdot \mathrm{t}^{-1}\right)$ and Hatfield $\left(67.8 \mathrm{~L} \cdot \mathrm{t}^{-1}\right)$ compared favourably with the value of $54.4 \mathrm{~L} \cdot \mathrm{t}^{-1}$ provided by Almodares and Hadi (2009), but lower than the value of $74.0 \mathrm{~L} \cdot \mathrm{t}^{-1}$ reported by Smith and Frederiksen (2000).

According to Zegada-Lizarazu et al. (2012), the theoretical ethanol yield of sweet sorghum in the US ranges from 2130 to $5700 \mathrm{~L} \cdot \mathrm{ha}^{-1}$ and depends on the environmental conditions (with the highest ethanol yields in the southern regions of the US). Miller and Ottman (2010) calculated a theoretical ethanol yield range of 2316 and $2878 \mathrm{~L} \cdot \mathrm{ha}^{-1}$ for different irrigation treatments. The trial was conducted in the US and gave an average ethanol yield of $2726 \mathrm{~L} \cdot \mathrm{ha}^{-1}$, which is similar to the yield of $2560 \mathrm{~L} \cdot \mathrm{ha}^{-1}$ reported by Wittenberg (2007).

\section{Water use efficiency (WUE)}

The WUE estimates of the sweet sorghum crop for the 2010/11 and 2011/12 growing seasons are presented in Tables 9 and 10
TABLE 5

Comparison of utilisable yield (stalk yield) for sweet sorghum at Ukulinga obtained from the 2010/11 and 2011/12 growing seasons

\begin{tabular}{|l|c|c|c|c|}
\hline Season & $\begin{array}{c}\text { Growing } \\
\text { period } \\
\text { (days) }\end{array}$ & $\begin{array}{c}\text { Plant density } \\
\text { (plants/ha) }\end{array}$ & $\begin{array}{c}\text { Fresh stalk } \\
\text { yield (t.ha-1) }\end{array}$ & $\begin{array}{c}\text { Dry stalk } \\
\text { yield (t.ha-1) }\end{array}$ \\
\hline $2010 / 11$ & 132 & 81813 & 24.4 & 4.9 \\
\hline $2011 / 12$ & 145 & 134609 & 41.8 & 9.3 \\
\hline
\end{tabular}

TABLE 6

Comparison of utilisable yield (stalk yield) for sweet sorghum at Hatfield obtained from the 2010/11 and 2011/12 growing seasons

\begin{tabular}{|l|c|c|c|c|}
\hline Season & $\begin{array}{c}\text { Growing } \\
\text { period } \\
\text { (days) }\end{array}$ & $\begin{array}{c}\text { Plant density } \\
\text { (plants/ha) }\end{array}$ & $\begin{array}{c}\text { Fresh stalk } \\
\text { yield (t.ha-1) }\end{array}$ & $\begin{array}{c}\text { Dry stalk } \\
\text { yield (t.ha-1) }\end{array}$ \\
\hline $2010 / 11$ & 139 & 55000 & 34.1 & 8.0 \\
\hline $2011 / 12$ & 145 & 86000 & 37.6 & 9.0 \\
\hline
\end{tabular}

TABLE 7

Comparison of the utilisable yield (stalk yield, sugar and ethanol) for sweet sorghum at Ukulinga obtained from the 2010/11 and 2011/12 growing seasons

\begin{tabular}{|c|c|c|c|c|c|}
\hline Season & $\begin{array}{c}\text { Stalk yield } \\
\left(t \cdot h a^{-1}\right)\end{array}$ & $\begin{array}{l}\text { Brix } \\
(\%)\end{array}$ & $\begin{array}{l}\text { Sugar } \\
\left(t \cdot h a^{-1}\right)\end{array}$ & $\begin{array}{c}\text { Ethanol } \\
\left(L \cdot h a^{-1}\right)\end{array}$ & $\begin{array}{c}\text { Extraction } \\
\text { yield } \\
\left(L \cdot t^{-1}\right)\end{array}$ \\
\hline 2010/11 & 24.4 & 8.9 & 2.2 & 1075 & 44.1 \\
\hline 2011/12 & 41.8 & 12.6 & 5.3 & 2606 & 62.3 \\
\hline
\end{tabular}

TABLE 8

Comparison of the utilisable yield (stalk yield, sugar and ethanol) for sweet sorghum at Hatfield obtained from the 2010/11 and 2011/12 growing seasons

\begin{tabular}{|c|c|c|c|c|c|}
\hline Season & $\begin{array}{c}\text { Stalk yield } \\
\left(\mathbf{t} \cdot \mathrm{ha}^{-1}\right)\end{array}$ & $\begin{array}{l}\text { Brix } \\
(\%)\end{array}$ & $\begin{array}{l}\text { Sugar } \\
\left(t \cdot h a^{-1}\right)\end{array}$ & $\begin{array}{c}\text { Ethanol } \\
\left(\text { L.ha- }{ }^{-1}\right)\end{array}$ & $\begin{array}{l}\text { Extraction } \\
\text { yield } \\
\left(L \cdot t^{-1}\right)\end{array}$ \\
\hline 2010/11 & 34.1 & 12.2 & 4.2 & 2059 & 60.4 \\
\hline $2011 / 12$ & 37.6 & 15.2 & 5.8 & 2828 & 75.2 \\
\hline
\end{tabular}

for Ukulinga and Hatfield experimental farms, respectively. Agronomic practices applied for both seasons were similar; although the average population was increased in the 2011/12 growing season at Ukulinga which increased the yield. The seasonal water use estimates were similar for both seasons taking into account the difference in the length of the growing period. Hence, WUE estimates were higher for the 2011/12 season compared to the 2010/11 growing season. The sweet sorghum yield estimates obtained at Hatfield experimental farm with a humid subtropical climate were higher than Ukulinga research farm which has a warm temperate climate. These higher yield estimates resulted in higher WUE of the sweet sorghum crop for Hatfield compared to Ukulinga research farm.

The WUE estimates of irrigated sweet sorghum, calculated for total dry matter (TDM) are given in Table 11. The results from this study ranged from 1.84 to $4.47 \mathrm{~kg} \cdot \mathrm{m}^{-3}$, which is broadly similar to the range of 2.43 to $2.88 \mathrm{~kg} \cdot \mathrm{m}^{-3}$ obtained by Miller and Ottman (2010). 
However, the $\mathrm{WUE}_{\mathrm{TDM}}$ values obtained in this study for irrigated sweet sorghum (Table 11) are lower than those reported in previous studies although most of the studies were undertaken on a different variety. Vasilakoglou et al. (2011) stated that the WUE of the total dry matter varied between 5.02 to $6.72 \mathrm{~kg} \cdot \mathrm{m}^{-3}$ for the same sweet sorghum cultivar (Sugargraze) depending on the applied supplemental irrigation and salinity conditions of the soil.

Experiments in Spain (Curt et al., 1995) obtained higher rates of $\mathrm{WUE}_{\mathrm{TDM}}$ for sweet sorghum (Keller variety) ranging from 3.74 to $5.43 \mathrm{~kg} \cdot \mathrm{m}^{-3}$. Mastrorilli et al. (1995) also conducted experiments on sweet sorghum (Keller variety) and concluded that the WUE of dry biomass $\left(5.18 \mathrm{~kg} \cdot \mathrm{m}^{-3}\right)$ was higher in comparison to other crops traditionally grown (e.g. sunflower, grain sorghum, and soybean) in the Mediterranean region. A study carried out by Steduto et al. (1997) on WUE of various $\mathrm{C}_{4}$ crops, including maize and grain sorghum, revealed the superior performance of sweet sorghum (WUE of $5.2 \mathrm{~kg} \cdot \mathrm{m}^{-3}$ ) in independent experiments carried out in Italy, Greece and Spain. Sakellariou-Makrantonaki et al. (2007) found WUE values of $5.3 \mathrm{~kg} \cdot \mathrm{m}^{-3}$ for sub-surface drip irrigated and $4.2 \mathrm{~kg} \cdot \mathrm{m}^{-3}$ for surface irrigated sweet sorghum (Keller variety) in central Greece. Similarly, the WUE values for sugar and ethanol yield for this study are lower than those reported globally.

\section{CONCLUSIONS}

Water use efficiency is influenced by many factors such as the variety or genotype of the crop, climatic conditions during the growth period, irrigation management, planting density and fertilizer application and other agronomic practices. WUE estimates were higher for the 2011/12 season compared to the 2010/11 growing season due to an increase in the average plant population density during the 2011/12 growing season which increased the yield significantly at Ukulinga only. The seasonal water use estimates were similar for both seasons and both sites taking into account the difference in the length of the growing period. However, the sweet sorghum yield estimates obtained at Hatfield research farm (a humid subtropical climate) were higher than Ukulinga research farm (warm temperate climate). These higher yield estimates resulted in higher WUE of the sweet sorghum crop for Hatfield compared to Ukulinga research farm.

The results from this study and the literature confirm that sweet sorghum has high WUE under a range of climatic and water supply conditions, and is therefore a suitable candidate feedstock for biofuel production. However agronomic studies are still needed. For example, the research conducted at Ukulinga and Hatfield showed that sweet sorghum yield is sensitive to planting density. The 'Sugargraze' variety tested in this study did not perform well for ethanol production compared to other varieties tested internationally, because it was bred mainly as a forage sorghum. However it did show potential as an ethanol feedstock. It should also be noted that currently there is limited availability of certified sweet sorghum seed worldwide. Although sweet sorghum has lower agronomic requirements compared to other sugar crops, its development as an energy crop is less advanced, due to the current lack of knowledge on management and recent breeding history. Further research is required to identify cultivars best suited to South Africa's growing conditions as well as agronomic practices which maximize yield.

South Africa is a water-scarce country and, in terms of the National Water Act of 1998, it is necessary to assess the potential water use and likely impact of potential biofuel feedstock production on water resources. The IWRM suggests that
TABLE 9

Comparison of water use efficiency (fresh stalk yield, sugar and ethanol) for sweet sorghum at Ukulinga obtained from the 2010/11 and 2011/12 growing seasons

\begin{tabular}{|l|c|c|c|}
\hline Season & $\begin{array}{l}\mathbf{W U E}_{\text {Yield }} \\
\left(\mathbf{k g} \cdot \mathbf{m}^{-3} \mathbf{)}\right.\end{array}$ & $\begin{array}{c}\mathbf{W U E}_{\text {Sugar }} \\
\mathbf{( k g} \cdot \mathbf{m}^{-3} \mathbf{)}\end{array}$ & $\begin{array}{c}\mathbf{W U E}_{\text {Ethanol }} \\
\left(\mathbf{L} \cdot \mathbf{m}^{-3} \mathbf{)}\right.\end{array}$ \\
\hline $2010 / 11$ & 6.19 & 0.56 & 0.27 \\
\hline $2011 / 12$ & 9.59 & 1.22 & 0.60 \\
\hline
\end{tabular}

TABLE 10

Comparison of water use efficiency (fresh stalk yield, sugar and ethanol) for sweet sorghum at Hatfield obtained from the 2010/11 and 2011/12 growing seasons

\begin{tabular}{|c|c|c|c|}
\hline Season & $\begin{array}{l}\text { WUE }_{\text {Yield }} \\
\left(\mathbf{k g} \cdot \mathrm{m}^{-3}\right)\end{array}$ & $\begin{array}{l}\text { WUE }_{\text {Sugar }} \\
\left(\mathbf{k g} \cdot \mathrm{m}^{-3}\right)\end{array}$ & $\begin{array}{c}\text { WUE }_{\text {Ethanol }} \\
\left(\mathbf{L} \cdot \mathbf{m}^{-3}\right)\end{array}$ \\
\hline $2010 / 11$ & 8.72 & 1.07 & 0.53 \\
\hline 2011/12 & 9.28 & 1.41 & 0.70 \\
\hline
\end{tabular}

TABLE 11

Water use efficiency estimates based on total dry matter (TDM) of sweet sorghum at Ukulinga and Hatfield for the 2010/11 and 2011/12 growing seasons

\begin{tabular}{|c|c|c|c|c|}
\hline Season & Location & $\begin{array}{c}\text { TDM } \\
\left(\mathbf{t} \cdot h \mathbf{a}^{-1}\right)\end{array}$ & $\begin{array}{c}\text { Water use } \\
\left(\mathbf{m}^{3} \cdot \mathbf{h a}^{-1}\right)\end{array}$ & $\begin{array}{l}\text { WUE }_{\text {TDM }} \\
\left(\mathbf{k g} \cdot \mathbf{m}^{-3}\right)\end{array}$ \\
\hline \multirow{2}{*}{ 2010/11 } & Ukulinga & 7.3 & 3940 & 1.85 \\
\hline & Hatfield & 14.2 & 3910 & 3.63 \\
\hline \multirow{2}{*}{$2011 / 12$} & Ukulinga & 13.1 & 4360 & 3.00 \\
\hline & Hatfield & 18.1 & 4050 & 4.47 \\
\hline
\end{tabular}

policymakers need to encourage farmers to grow biofuel crops under rainfed conditions. The South African Department of Water Affairs (now the Department of Water and Sanitation) has also made a decision not to support the production of biofuels under irrigation. Biofuel feedstocks which use less water, such as sweet sorghum, are likely to have much less impact on water resources. Furthermore, according to the Department of Minerals and Energy biofuel production in South Africa is also driven by the need for rural development and poverty eradication. It is likely that sweet sorghum can be grown in rainfed areas and on marginal lands due to its adaptability to drought and other environmental conditions and can thus open up opportunities for small-scale farmers as it exhibits a higher rural development potential.

\section{ACKNOWLEDGEMENTS}

The research presented in this paper forms part of a solicited research project (Water use of cropping systems adapted to bio-climatic regions in South Africa and suitable for biofuel production) that was initiated by the Water Research Commission (WRC) of South Africa in Key Strategic Area on Water Utilisation in Agriculture). The project was managed and funded by the WRC. For further information, refer to Project No. 1874 on pages $153-154$ of the WRC's Knowledge Review 2009/10 publication, obtainable from their website (WRC, 2010). We thank the ACCI staff and Mr Ofentse Mokonoto (UKZN) for the technical support and assistance during the field trials. 


\section{REFERENCES}

AGRICULTURE BUSINESS WEEK (2010) Sweet sorghum residues make good bio-organic fertilizer. ABW Online. URL: http://www. agribusinessweek.com/sweet-sorghum-residues-make-good-bioorganic-fertilizer/ (Accessed 16 October 2010).

ALEMAYEHU YA, STEYN JM and ANNANDALE JG (2009) FAOtype crop factor determination for irrigation scheduling of hot pepper (Capsicum annuum L.) cultivars. S. Afr. J. Plant Soil. 26 186-194. http://dx.doi.org/10.1080/02571862.2009.10639953

ALMODARES A and HADI MR (2009) Production of bioethanol from sweet sorghum: A review. Afr. J. Agric. Res. 4 (9) 772-780.

CALDER IR (2005) Blue Revolution II, Integrated Land \& Water Resources Management. Earthscan Publishers, London. 353 pp.

CAMP KG (1997) The Bioresource Groups of KwaZulu-Natal. Cedara: KwaZulu-Natal Department of Agriculture. Cedara Report No. N/A/97/6. KZN DoA, Pietermaritzburg. 84 pp.

CURT MD, FERNANDEZ J and MARTINEZ M (1995) Productivity and water use efficiency of sweet sorghum (Sorghum bicolor (L.) Moench) cv. "Keller" in relation to water regime. Biomass Bioenerg. 8 (6) 401-409. http://dx.doi.org/10.1016/0961-9534(95)00036-4

DAFF (DEPARTMENT OF AGRICULTURE, FORESTRY AND FISHERIES, SOUTH AFRICA) (2010) Sorghum: Production guideline. URL: http://www.nda.agric.za/docs/Brochures/prodGuideSorghum.pdf (Accessed 15 October 2015).

DERCAS N, KAVADAKIS G and LIAKATAS A (2001) Evaluation of productivity, water and radiation use efficiency of two sweet sorghum varieties under Greek conditions. In: Proceedings of $1^{\text {st }}$ World Conference on Biomass for Energy and Industry: 5-9 June 2000, Sevilla, Spain.

DERCAS N, LIAKATAS A (2007) Water and radiation effect on sweet sorghum productivity. Water Resour. Manage. 21 1585-1600. http:// dx.doi.org/10.1007/s11269-006-9115-2

DME (DEPARTMENT OF MINERALS AND ENERGY, SOUTH AFRICA) (2007) Biofuels industrial strategy of the Republic of South Africa, Pretoria, South Africa. URL: http://www.dme.gov.za/ pdfs/energy/renewable/biofuels_indus_strat.pdf(2).pdf (Accessed 14 February 2013). 29 pp.

FSSA (FERTILIZER SOCIETY OF SOUTH AFRICA) (2003) Fertilizer Handbook. Fifth Revised Edition. 5.20. Fertilization of Pastures and Fodder Crops. FSSA, Pretoria. ISBN: 0-909071-85-3.

GRAFTON QR and HUSSEY K (2011) Water Resources Planning and Management. Cambridge University Press, New York.

GUIYING L, WEIBIN G, HICKS A and CHAPMAN KR (2003) Training manual for sweet sorghum. FAO Project TCP/CPR/0066. URL: http://ecoport.org/ep?SearchType=earticleView\&earticleId=1 72 \&page $=-2$ (Accessed 29 September 2012).

IWMI (INTERNATIONAL WATER MANAGEMENT INSTITUTE) (2008) Water implications of biofuel crops: Understanding tradeoffs and identifying options. IWMI Water Policy Brief Issue 30. International Water Management Institute (IWMI), Colombo, Sri Lanka. URL: http://www.iwmi.cgiar.org/Publications/Water_ Policy_Briefs/PDF/WPB30.pdf(Accessed 16 February 2013). 4 pp.

JEWITT GPW and KUNZ RP (2011) The impact of biofuel feedstock production on water resources: a developing country perspective. Biofuels Bioprod. Biorefin. 5 387-398. http://dx.doi.org/10.1002/ bbb. 314

K2 SEED MARKETING (2015) Sugargraze cultivar characteristics.URL: http://www.seedmarketing.co.za/docs/FORAGE SORGHUMSUGARGRAZE2014.pdf (Accessed 15 October 2015).

LORENTZ S, GOBA P and PRETORIUS J (2001) Hydrological processes: Experiments and measurements of soil hydraulic characteristics. WRC Report No. 744/1/01. Water Research Commission, Pretoria. 69 pp.

MASTRORILLI M, KATERJI N, RANA G, and STEDUTO P (1995) Sweet sorghum in Mediterranean climate: radiation use and biomass water use efficiencies. Ind. Crops Prod. 3 253-260. http:// dx.doi.org/10.1016/0926-6690(94)00002-G

MENGISTU MG and SAVAGE MJ (2010) Surface renewal method for estimating sensible heat flux. Water SA 36 (1) 9-18. http://dx.doi. org/10.4314/wsa.v36i1.50902

MILLER AN and OTTMAN MJ (2010) Irrigation frequency effects on growth and ethanol yield in sweet sorghum. Agron. J. 102(1) 60-70. http://dx.doi.org/10.2134/agronj2009.0191

MOODLEY M, JOHNSTON MA, HUGHES JC and TITSHALL LW (2004) Effects of water treatment residues, lime, gypsum, and polyacrylamide on the water retention and hydraulic conductivity of two contrasting soils under field conditions in KwaZuluNatal, South Africa. Aust. J. Soil Res. 42 273-282. http://dx.doi. org/10.1071/SR03045

MUL ML (2009) Understanding hydrological processes in an ungauged catchment in sub-Saharan Africa. PhD thesis, UNESCOIHE, Delft, The Netherlands.

NOMQUPHU W, BRAUNE E and MITCHELL S (2007) The changing water resources monitoring environment in South Africa. S. Afr. J. Sci. 103 306-310.

PASSIOURA JB and ANGUS JF (2010) Improving productivity of crops in water-limited environments. In: Sparks DL (ed.) Advances in Agronomy, Vol. 106. Academic Press, Burlington. 37-75. http:// dx.doi.org/10.1016/s0065-2113(10)06002-5

PAW UKT, SNYDER RL, SPANO D and SU HB (2005) Surface renewal estimates of scalar exchange. In: Hatfield JL and Baker JM (ed.) Micrometeorology in Agricultural Systems. Agronomy Monograph, Vol. 47. American Society of Agronomy, Madison, WI. 455-483.

RAO SS, PATIL JV, PRASAD PVV, REDDY DCS, MISHRA JS, UMAKANTH AV, REDDY BVS and KUMAR AA (2013) Sweet sorghum planting effects on stalk yield and sugar quality in semiarid tropical environment. Agron. J. 105(5) 1458-1465. http:// dx.doi.org/10.2134/agronj2013.0156

REDDY BVS, KUMAR AA and RAMESH S (2007) Sweet sorghum: A water saving bio-energy crop. International Crops Research Institute for the SemiArid Tropics (ICRISAT), Patancheru, Andhra Pradesh, India. URL: http://www.iwmi.cgiar.org/EWMA/ files/papers/Paper\%20for\%20Bioenergy\%20and\%20waterBelumReddy.pdf (Accessed 16 October 2010).

SAKELLARIOU-MAKRANTONAKI M, PAPALEXIS D, NAKOS N and KALAVROUZIOTIS IK (2007) Effects of modern irrigation methods on growth and energy production of sweet sorghum (var. Keller) on a dry year in central Greece. Agric. Water Manage. 90 181-189. http://dx.doi.org/10.1016/j.agwat.2007.03.004

SMITH CW and FREDERIKSEN RA (2000) Sorghum: Origin, History, Technology, and Production. John Wiley and Sons, New York. 824 pp.

SOIL CLASSIFICATION WORKING GROUP (1991) Soil Classification: A Taxonomic System for South Africa. Soil and Irrigation Research Institute, Department of Agricultural Development, Pretoria, South Africa. ISBN: 0-621-10784-0.

STEDUTO P, KATERJI N, PUERTOS-MOLINA H, ÜNULU M, MASTRORILLI M and RANA G (1997) Water-use efficiency of sweet sorghum under water stress conditions gas-exchange investigations at leaf and canopy scales. Field Crops Res. 54 221-234. http://dx.doi.org/10.1016/S0378-4290(97)00050-6

TURHOLLOW AF, WEBB EG, DOWNING ME (2010) Review of sorghum production practices: Applications for bioenergy. ORNL/ TM-2010/7.Oak Ridge National Laboratory, Tennessee, US. URL: http://info.ornl.gov/sites/publications/files/Pub22854.pdf (Accessed 2 June 2011). http://dx.doi.org/10.2172/982121

USDoE (UNITED STATES DEPARTMENT OF ENERGY) (2011) U.S. Billion-Ton Update: Biomass Supply for a Bioenergy and Bioproducts Industry. RD Perlack and BJ Stokes (Leads), ORNL/ TM-2011/224. Oak Ridge National Laboratory, Oak Ridge, TN. URL: http://wwwl.eere.energy.gov/bioenergy/pdfs/billion_ton_ update.pdf (Accessed 15 August 2013). 227 pp.

VAN ATTA CW (1977) Effect of coherent structures on structure functions of temperature in the atmospheric boundary layer. Arch. Mech. 29 161-171.

VASILAKOGLOU I, DHIMA K, KARAGIANNIDIS N and GATSIS T (2011) Sweet sorghum productivity for biofuels under increased soil salinity and reduced irrigation. Field Crops Res. 120 38-46. http:// dx.doi.org/10.1016/j.fcr.2010.08.011

WRC (WATER RESEARCH COMMISSION) (2010) WRC Knowledge Review 2009/10. URL: http://www.wrc.org.za/Knowledge\%20 Hub\%20Documents/Knowledge\%20Reviews/Knowledge\%20 Review\%202009-\%2010.pdf (Accessed 24 February 2014). 
WITTENBERG E (2007) Preliminary evaluation of sweet sorghum (Sorghum bicolor (L.) Moench) as a feedstock for ethanol production in Arizona. MSc thesis, Plant Sciences Department, University of Arizona.

WU X, STAGGENBORG S, PROPHETER JL, ROONEY WL, YU J and WANG D (2010) Features of sweet sorghum juice and their performance in ethanol fermentation. Ind. Crops Prod. 31 (1) 164-170. http://dx.doi.org/10.1016/j.indcrop.2009.10.006

ZEGADA-LIZARAZU W, ZATTA A and MONTI A (2012) Water uptake efficiency and above- and below-ground biomass development of sweet sorghum and maize under different water regimes. Plant Soil 351 (1,2) 47-60. http://dx.doi.org/10.1007/ s11104-011-0928-2

ZHAO YL, DOLAT A, STEINBERGER Y, WANG X, OSMAN A and XIE GH (2009) Biomass yield changes in chemical composition of sweet sorghum cultivars grown for biofuel. Field Crops Res. 111 55-64. http://dx.doi.org/10.1016/j.fcr.2008.10.006 